\title{
Divergent Reactivity of 2-Vinylpyridine and 1-Vinylpyrazole in Rhodium-Phosphine Systems: C-H Activation and Dinuclear Chemistry
}

\author{
Ramón Azpíroz, ${ }^{1}$ Vincenzo Passarelli, ${ }^{1,2}$ Ricardo Castarlenas, ${ }^{*}, 1$ Jesús J. Pérez-Torrente, ${ }^{1}$ and Luis A. Oro*,1 \\ 1 Departamento de Química Inorgánica - Instituto de Síntesis Química y Catálisis Homogénea-ISQCH, Universidad de Zaragoza \\ - CSIC, C/ Pedro Cerbuna 12, 50009 Zaragoza, Spain \\ 2 Centro Universitario de la Defensa, Ctra Huesca S/N 50090 Zaragoza, Spain
}

This paper is dedicated to the memory of Roberto Sanchez Delgado, an outstanding Latin American scientist and very good friend, who recently passed away.

Received October 18 $8^{\text {th }}, 2016$; Accepted March $8^{\text {th }}, 2017$.

\begin{abstract}
The $R h^{\mathrm{I}}-\mathrm{Rh}^{\mathrm{III}}$ mixed valence dinuclear complex $\mathrm{Rh}_{2^{-}}$ $\mathrm{Cl}_{2}(\mu-\mathrm{H})\left(\mu-\eta^{2}, \kappa^{2}-\mathrm{C}, \mathrm{N}-\mathrm{NC}_{5} \mathrm{H}_{4}-2-(Z) \mathrm{CH}=\mathrm{CH}\right)\left(\mathrm{PPhMe}_{2}\right)_{3}$ has been prepared by reaction of $\left[\mathrm{Rh}(\mu-\mathrm{Cl})\left(\eta^{2} \text {-coe }\right)_{2}\right]_{2}$ with 2 -vinylpyridine in the presence of dimethylphenylphosphine as a result of C-H activation of the terminal olefinic proton. The X-ray structure presents anagostic $\mathrm{Rh} \cdots \mathrm{HC}$ and $\pi-\pi$ interactions between aromatic rings. In contrast, 1-vinylpyrazole does not undergo a $\mathrm{C}$-H activation process, resulting in the formation of dinuclear species supported by 1-vinylpyrazole bridges. Anagostic $\mathrm{Rh} \cdots \mathrm{HC}$ interactions and $\mathrm{CH} \cdots \mathrm{Cl}$ hydrogen bonds are responsible for the 3D packing of the complex.

Keywords: C-H Activation; Vinylpyridine; Vinylpyrazole; Rhodium; Dinuclear Complexes.
\end{abstract}

\section{Introduction}

Transition-metal mediated $\mathrm{C}$-H activation has become a pivotal tool for synthetic chemists [1]. The presence of a nucleophilic directing group typically promotes the selective cleavage of the $\mathrm{C}-\mathrm{H}$ bond by approaching it to the metallic center. In this context, pyridine and pyrazole scaffolds constitute a prevalent family of auxiliaries which have been successfully applied in the activation of aromatic, olefinic or even aliphatic C-H bonds [2]. Nevertheless, in order to exert a better control on the catalytic performance, a detailed knowledge of the mechanism of the process is essential. Therefore, stoichiometric reactivity studies on selected organometallic precursors with substrates amenable for $\mathrm{C}-\mathrm{H}$ activation is of great interest.

In this context, our research group has recently disclosed new catalytic coupling reactions between 2-vinylpyridine [3] and 1-vinylpyrazole [4] with alkynes mediated by rhodium catalysts bearing N-heterocyclic carbenes (NHC) [5]. In both catalytic systems $\mathrm{C}-\mathrm{H}$ activation of the heteroaromatic olefin has been proposed as key step. Interestingly, a rhodium-hydrido-IPr $\{$ IPr $=$ 1,3-bis-(2,6-diisopropylphenyl)imidazol-2-carbene $\}$ intermediate could be detected in the case of 1-vinylpyrazole but similar species was not observed for 2-vinylpyridine (Scheme
Resumen. El complejo dinuclear de valencia mixta $\mathrm{Rh}^{\mathrm{I}}-\mathrm{Rh}^{\mathrm{III}} \mathrm{Rh}_{2}$ $\mathrm{Cl}_{2}(\mu-\mathrm{H})\left(\mu-\eta^{2}, \kappa^{2}-\mathrm{C}, \mathrm{N}-\mathrm{NC}_{5} \mathrm{H}_{4}-2-(Z) \mathrm{CH}=\mathrm{CH}\right)\left(\mathrm{PPhMe}_{2}\right)_{3}$ ha sido preparado por reacción de $\left[\mathrm{Rh}(\mu-\mathrm{Cl})\left(\eta^{2} \text {-coe }\right)_{2}\right]_{2}$ con 2-vinilpiridina en presencia de dimetilfenilfosfina, como resultado de la activación $\mathrm{C}-\mathrm{H}$ del protón terminal de la olefina. La estructura de rayos-X presenta enlaces anagósticos $\mathrm{Rh} \cdots \mathrm{HC}$, así como interacciones $\pi-\pi$ entre anillos aromáticos. Por otro lado, la reacción con 1-vinilpirazol no da lugar a una activación C-H sino que se observa la formación de una especie dinuclear soportada por ligandos 1-vinilpirazol puente. Diferentes interacciones anagósticas $\mathrm{Rh} \cdots \mathrm{HC}$ y de enlace de hidrógeno $\mathrm{CH} \cdots \mathrm{Cl}$ son responsables del empaquetamiento tridimensional del complejo. Palabras clave: Activación C-H; Vinilpiridina; Vinilpirazol; Rodio; Complejos Dinucleares.

1). We now hypothesize that reducing the steric hindrance of the two-electron donor ligand present in the catalyst precursor, by replacing the bulky NHC ligand with a small phosphine, may help in the stabilization of the hydrido-vinyl-rhodium(III) species. Thus, we present herein the very different reactivity of 2-vinylpyridine and 1-vinylpyrazole with a rhodium(I) precursor in the presence of less sterically encumbered dimethylphenylphosphine ligand.

\section{Results and discussion}

Treatment of an orange toluene solution of $\left[\mathrm{Rh}(\mu-\mathrm{Cl})\left(\eta^{2}-\mathrm{coe}\right)_{2}\right]_{2}$ (1) (coe $=$ cyclooctene) with 2-vinylpyridine and dimethylphenylphosphine (P:Rh ratio of 2:1) led, after $1 \mathrm{~h}$ at room temperature, to the formation of a red solid characterized as the $\mathrm{Rh}^{\mathrm{I}}-\mathrm{Rh}^{\mathrm{III}}$ mixed valence dinuclear complex $\mathrm{Rh}_{2} \mathrm{Cl}_{2}(\mu-\mathrm{H})$ $\left(\mu-\eta^{2}, \kappa^{2}-\mathrm{C}, \mathrm{N}-\mathrm{NC}_{5} \mathrm{H}_{4}-2-(Z) \mathrm{CH}=\mathrm{CH}\right)\left(\mathrm{PPhMe}_{2}\right)_{3}$ (2). When the reaction was conducted under the same conditions with the correct stoichiometry ( $\mathrm{P}: \mathrm{Rh}$ ratio of 1.5:1), the dinuclear derivative 2 was isolated in 73\% yield (Scheme 2). Complex 2 is the result of the $\mathrm{C}-\mathrm{H}$ bond activation in 2-vinylpyridine to form a hydrido- $\mathrm{Rh}^{\mathrm{III}}$-alkenyl cyclometalated intermediate, which is 

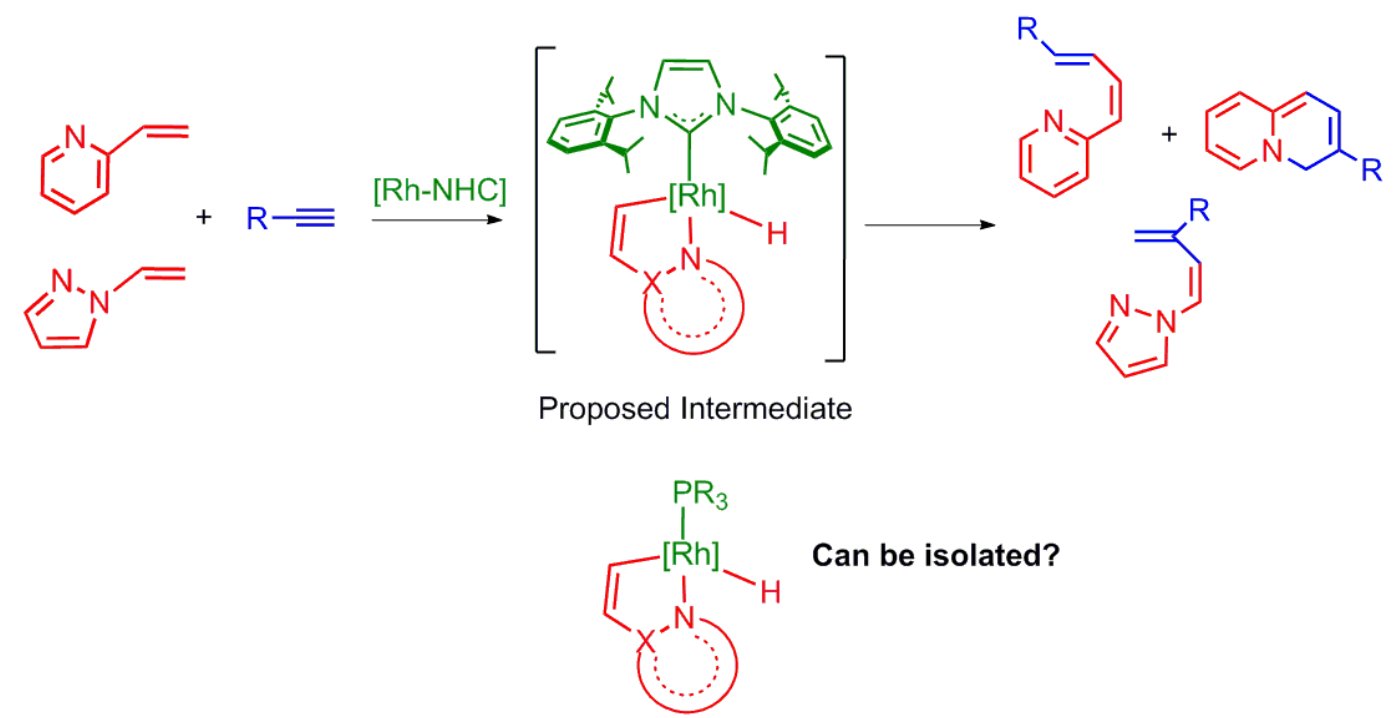

Scheme 1. C-H activation as key step in C-C catalytic coupling reactions.

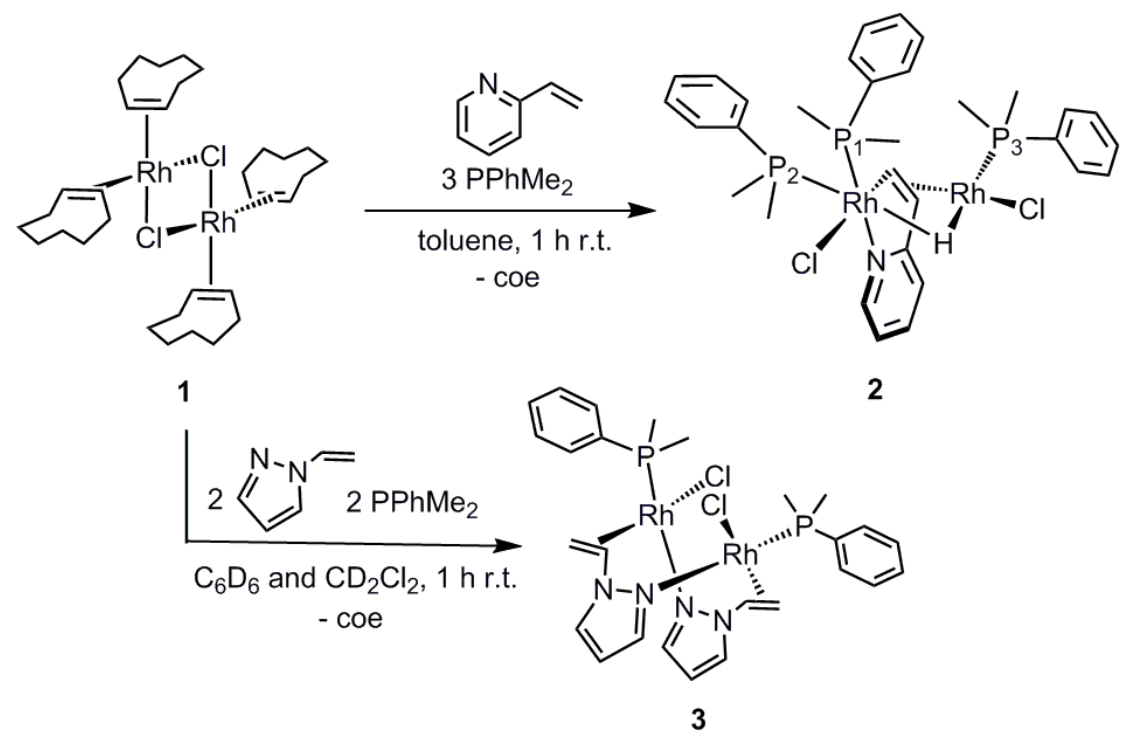

Scheme 2. Formation of dinuclear complexes 2 and $\mathbf{3}$.

stabilized by the formation of both hydrido and olefin bridges to a phosphine- $\mathrm{Rh}^{\mathrm{I}}$ fragment. The bridging coordination mode of the 2-(pyridin-2-yl)vinyl ligand in organometallic complexes is unusual but not unprecedented [6].

Complex 2 is very sensitive to oxygen and moisture and even slowly decomposes in $\mathrm{CD}_{2} \mathrm{Cl}_{2}$ solutions, so satisfactory elemental analysis could not be obtained. However, the compound has been unambiguous characterized in solution by multinuclear NMR spectroscopy and in the solid state by X-ray diffraction analysis. Figure 1 reports the ORTEP view of $\mathbf{2}$ and a selection of bond lengths and angles. The complex contains two rhodium centers, $\mathrm{Rh}(1)$ with a octahedral environment and $\mathrm{Rh}(2)$ with a square planar geometry. The coordination sphere at $\mathrm{Rh}(1)$ - formally a $\mathrm{Rh}^{\mathrm{III}}$ centre - contains two phosphorus atoms in a cis arrangement and one chlorido ligand cis to both $\mathrm{P}(1)$ and $\mathrm{P}(2)$. The remaining coordination sites are occupied by the bridging hydrido ligand trans to $\mathrm{P}(2)$ and the bidentate $\kappa^{2}-\mathrm{C}, \mathrm{N} 2$ 2-(pyridin-2-yl)vinyl moiety with the pyridine nitrogen atom $\mathrm{N}(48)$ located trans to $\mathrm{P}(1)$. The pyridine ring displays pitch and yaw angles of $3.1^{\circ}$ and $7.9^{\circ}$, respectively [4]. The coordination polyhedron at $\mathrm{Rh}(2)$ - formally a $\mathrm{Rh}^{\mathrm{I}}$ centre - is square planar with a T-shaped arrangement of $\mathrm{P}(3), \mathrm{Cl}(2)$ and $\mathrm{H}(1)$ and the $\eta^{2}$ vinyl moiety $\mathrm{C}(41)-\mathrm{C}(42)$ in the remaining coordination site trans to $\mathrm{Cl}(2)$. The $\eta^{2}$-vinyl moiety lays out of the coordination plane of $\mathrm{Rh}(2)$, indeed the angle between the least square planes $\mathrm{Rh}(2)-\mathrm{C}(41)-\mathrm{C}(42)$ and $\mathrm{Rh}(2)-\mathrm{H}(1)-\mathrm{Cl}(2)-\mathrm{P}(3)$ is $67.5^{\circ}$. 
Remarkably the short intermetallic distance $\{\mathrm{Rh}(1) \cdots \mathrm{Rh}(2)$ $2.8130(2) \AA$ \} should be consequence of the small bridging hydrido ligand rather than of an intermetallic bond or interaction. In addition, $\pi$-stacking between the phenyl ring of the phosphine(3) and the pyridyl moiety induces a parallel offset arrangement of the above mentioned aromatic rings [7] (Figure 2). More interestingly, pairs of dinuclear complexes are joined together by means of $\mathrm{Rh}(2) \cdots \mathrm{H}(35)-\mathrm{C}(35)$ anagostic interactions $\left\{\mathrm{Rh}(2) \cdots \mathrm{H}(35)\right.$ 2.82(3) $\AA$; $\left.\mathrm{C}(35)-\mathrm{H}(35)-\mathrm{Rh}(2) 151(1)^{\circ}\right\}$ [8].

The structure of $\mathbf{2}$ in the solid state is maintained in solution, as inferred from the NMR spectra. The ${ }^{31} \mathrm{P}\left\{{ }^{1} \mathrm{H}\right\}$ NMR spectrum show three doublets of doublets of doublets of doublets corresponding to the inequivalent phosphine ligands as a consequence of the phosphorus-phosphorus and phosphorus-rhodium couplings (table 1 and Figure 3). All three phosphorus atoms couple each other and with both NMR active rhodium centers. The higher coupling constant for each phosphorus resonance corresponds to the directly attached rhodium atom. We assigned that of $176 \mathrm{~Hz}$ to the phosphine $\mathrm{P}(3)$, attached to the $\mathrm{Rh}^{\mathrm{I}}$ center, whereas the two others correspond to the phosphines coordinated to $\mathrm{Rh}^{\mathrm{III}}$ centre $\left\{{ }^{1} J_{\mathrm{P}-\mathrm{Rh}}=115 \mathrm{~Hz}\right.$ $\mathrm{P}(1), 111 \mathrm{~Hz} \mathrm{P}(2)\}$. Small $J_{\mathrm{P}-\mathrm{Rh}}$ values were observed with the

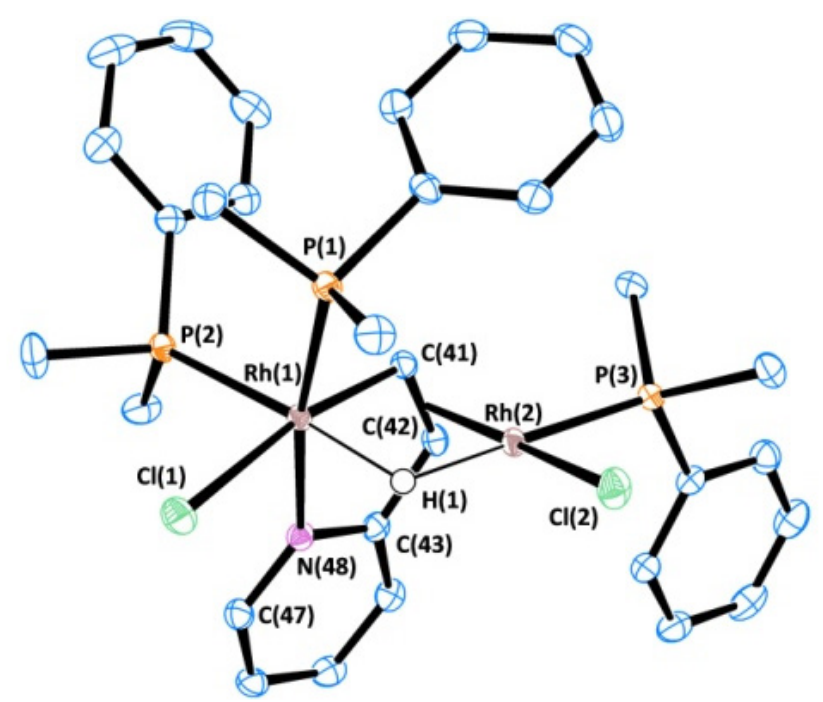

Figure 1. ORTEP view of the X-ray structure of 2 with the numbering scheme adopted. Most hydrogen atoms are omitted for clarity. Ellipsoids are at $50 \%$ probability. Selected bond lengths $(\AA)$ and angles $\left({ }^{\circ}\right)$ (ct: centroid): $\mathrm{Rh}(1)-\mathrm{N}(48) 2.1125(15), \mathrm{Rh}(1)-\mathrm{P}(1) 2.2468(5), \mathrm{Rh}(1)-\mathrm{P}(2) 2.3210(5)$, $\mathrm{Rh}(2)-\mathrm{P}(3)$ 2.2403(5), $\mathrm{Rh}(1)-\mathrm{H}(1)$ 1.70(2), $\mathrm{Rh}(2)-\mathrm{H}(1)$ 1.80(2), $\mathrm{Rh}(1)-\mathrm{Cl}(1)$ 2.5044(5), $\mathrm{Rh}(2)-\mathrm{Cl}(2) \quad 2.3801(5), \mathrm{Rh}(1) \cdots \mathrm{Rh}(2) \quad 2.8130(2)$, $\mathrm{Rh}(1)-\mathrm{C}(41)$ 2.0026(18), Rh(2)-ct[C(41)-C(42)] 1.95779(17), C(41)-C(42) 1.425(2), C(41)-Rh(1)-N(48) 81.89(7), N(48)-Rh(1)-P(1) 170.56(4), $\mathrm{P}(1)-\mathrm{Rh}(1)-\mathrm{P}(2)$ 98.123(17), $\mathrm{P}(2)-\mathrm{Rh}(1)-\mathrm{H}(1)$ 175.4(7)， ct[C(41)-C(41)]-Rh(2)-P(3) 96.564(14), ct[C(41)-C(41)]-Rh(2)-Cl(2)169.502(13), $\operatorname{ct}[\mathrm{C}(41)-\mathrm{C}(41)]-\mathrm{Rh}(2)-\mathrm{H}(1)$ 88.4(7), $\mathrm{P}(3)-\mathrm{Rh}(2)-\mathrm{H}(1)$ 174.8(7).

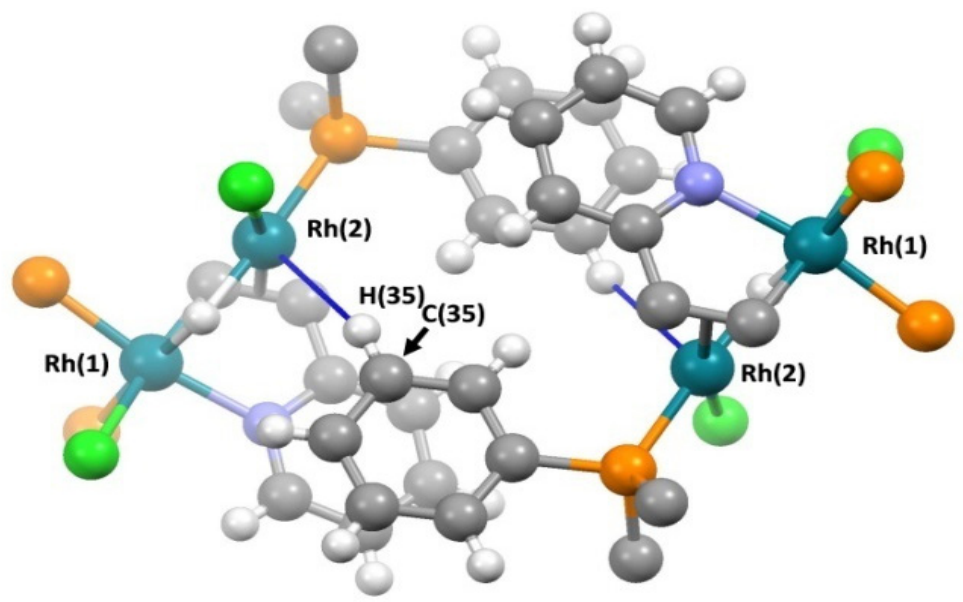

Figure 2. Two molecules of 2 related by an inversion centre, showing the anagostic $\mathrm{Rh} \cdots \mathrm{HC}$ interaction (blue) and the $\pi$-stacking of the $\mathrm{P}(3)$ phenyl ring and the pyridyl moiety. Most hydrogen atoms and the $\mathrm{P}(1)$ - and $\mathrm{P}(2)$-substituents are omitted for clarity. $\mathrm{H}(35) \cdots \mathrm{Rh}(2) 2.82(3) \AA$; $\mathrm{C}(35)-\mathrm{H}(35)-\mathrm{Rh}(2) 151(1)^{\circ}$. 
Table 1. Scalar Couplings (Hz) between NMR active heteroatoms of 2.

\begin{tabular}{cccccc}
\hline $\mathrm{J}$ & $\mathrm{Rh}(1)$ & $\mathrm{Rh}(2)$ & $\mathrm{P}(1)$ & $\mathrm{P}(2)$ & 111 \\
\hline $\mathrm{Rh}(1)$ & - & - & 115 & $3(3)$ & 10 \\
$\mathrm{Rh}(2)$ & - & - & 3 & 27 & 176 \\
$\mathrm{P}(1)$ & 115 & 3 & - & 27 & 3 \\
$\mathrm{P}(2)$ & 111 & 7 & 3 & 56 & - \\
$\mathrm{P}(3)$ & 10 & 176 & 56 & \\
\hline
\end{tabular}

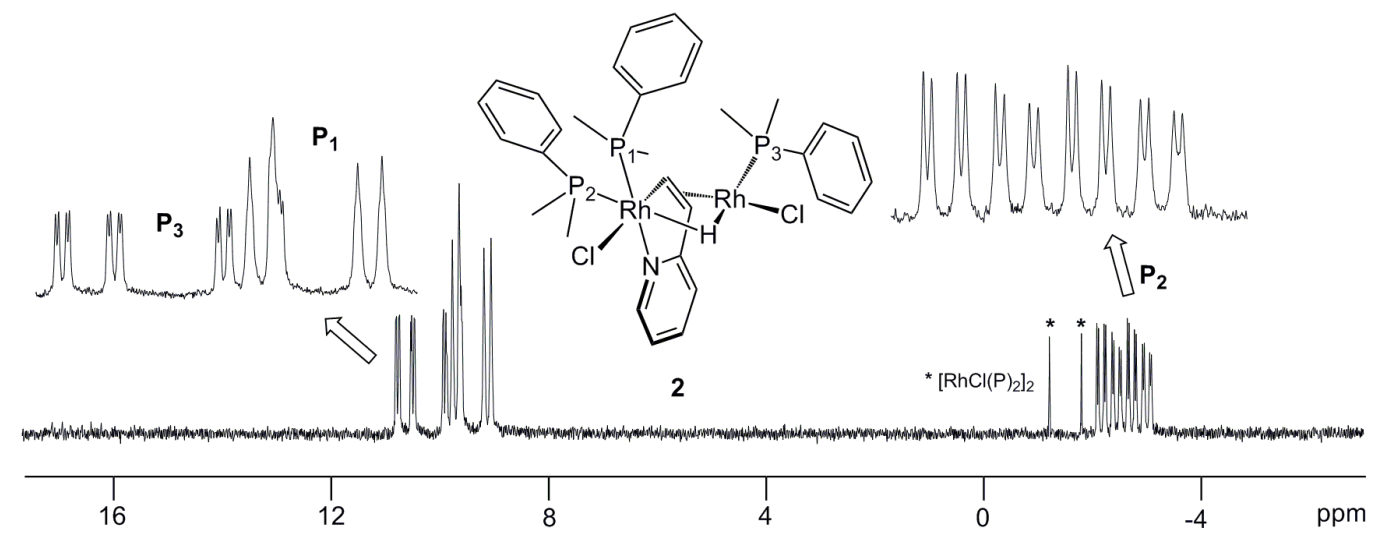

Figure 3. ${ }^{31} \mathrm{P}$ NMR spectra of 2 in $\mathrm{C}_{6} \mathrm{D}_{6} / \mathrm{CD}_{2} \mathrm{Cl}_{2}$ at $298 \mathrm{~K}$.

remote metal atom $\left\{^{3} J_{\mathrm{P}-\mathrm{Rh}}=3 \mathrm{~Hz}, \mathrm{P}(1) ; 7 \mathrm{~Hz}, \mathrm{P}(2) ; 10 \mathrm{~Hz}\right.$, $\mathrm{P}(3)\}$. Regarding the P-P couplings, the higher one $(56 \mathrm{~Hz})$ is attributed to in plane $\mathrm{P}(2)-\mathrm{Rh}^{\mathrm{I}}-\mathrm{Rh}^{\mathrm{III}}-\mathrm{P}(3)$ arrangement. The two phosphines bonded to the $\mathrm{Rh}^{\mathrm{III}}$ atom coupled each other with a ${ }^{2} J_{\text {P-P }}=27 \mathrm{~Hz}$, while the smaller value of $3 \mathrm{~Hz}$ are observed for the out of plane $\mathrm{P}(1)-\mathrm{Rh}^{\mathrm{I}}-\mathrm{Rh}^{\mathrm{III}}-\mathrm{P}(3)$ interaction.

The most characteristic resonance in the ${ }^{1} \mathrm{H}$ NMR spectrum of 2 is a complex signal at $\delta-11.40$ ppm corresponding to the hydrido ligand which couples with the three phosphorus atoms and the two metals (Figure 4d). ${ }^{1} \mathrm{H}\left\{{ }^{31} \mathrm{P}\right\}$ NMR allowed for the determination of two ${ }^{1} J_{\mathrm{H}-\mathrm{Rh}}$ of 17 and $20 \mathrm{~Hz}$, typical for a saturated $\mathrm{Rh}^{\mathrm{III}}$ - or a square planar $\mathrm{Rh}^{\mathrm{I}}$-hydrido complexes (Figure $4 c$ ). The values for the hydrido-phosphorus coupling can be determined via selective ${ }^{1} \mathrm{H}\left\{{ }^{31} \mathrm{P}\right\}$ NMR experiments by irradiation either on the $\mathrm{P}_{1,3}$ (Figure $4 a$ ) or $\mathrm{P}_{2}$ (Figure $4 b$ ) shifts alternatively, giving rise to 18 and $50 \mathrm{~Hz}$ for ${ }^{2} J_{\mathrm{H}-\mathrm{P}(1,3)}$ and 128 $\mathrm{Hz}$ for ${ }^{2} J_{\mathrm{H}-\mathrm{P}(2)}$. In addition, two doublets corresponding to the alkenyl protons were observed in the ${ }^{1} \mathrm{H}$ NMR spectrum at $\delta$ 6.54 and $3.00 \mathrm{ppm}$ with a mutual coupling of $4.8 \mathrm{~Hz}$, indicating a $Z$ stereochemistry and coordination to the metallic center. The Rh-alkenyl $\mu-\eta^{2}$ ligand was confirmed by the appearance in the ${ }^{13} \mathrm{C}\left\{{ }^{1} \mathrm{H}\right\}$ NMR spectrum of a multiplet appearing at $\delta 133.9$ ppm, assigned to metallated carbon, and a doublet of doublets of doublets at $59.6 \mathrm{ppm}\left({ }^{1} J_{\mathrm{C}-\mathrm{Rh}}=12.9 \mathrm{~Hz},{ }^{2} J_{\mathrm{C}-\mathrm{P}}={ }^{2} J_{\mathrm{C}-\mathrm{Rh}}=3.0 \mathrm{~Hz}\right)$ corresponding to the vinylic carbon attached to pyridine ring.

In contrast to the formation of the hydrido-alkenyl complex 2 , treatment of 1 with 1-vinylpyrazole in the presence of dimethylphenylphosphine (P:Rh ratio of $1: 1)$ did not result in the cleavage of the olefinic $\mathrm{C}-\mathrm{H}$ bond. Instead, the dinuclear $\mathrm{Rh}^{\mathrm{I}}$ complex $\mathrm{Rh}_{2} \mathrm{Cl}_{2}\left(\mu-\eta^{2}, \mathrm{~N}_{2} \mathrm{C}_{3} \mathrm{H}_{3}-1-\mathrm{CH}=\mathrm{CH}_{2}\right)\left(\mathrm{PPhMe}_{2}\right)_{3}$ (3) was obtained in which the 1-vinylpyrazole act as a bridge through the $\mathrm{C}=\mathrm{C}$ bond and a nitrogen atom. Several attempts of isolation of $\mathbf{3}$ failed and just starting material was recovered indicating that the formation of $\mathbf{3}$ is reversible. However, complex 3 has been characterized in situ by multinuclear NMR and by a X-ray diffraction analysis on a single crystal. Heating of a sample of $\mathbf{3}$ resulted in a mixture of unidentified products with trace of hydrido signals.

Crystals of $\mathbf{3}$ were obtained by evaporation of a $\mathrm{C}_{6} \mathrm{D}_{6}: \mathrm{CD}_{2}-$ $\mathrm{Cl}_{2}$ solution of the compound and the solid state structure was determined by single crystal X-ray diffraction measurements. Figure 5 reports the ORTEP view of the complex and a selection of bond lengths and angles. The dinuclear complex is supported by two 1-vinylpyrazole ligands with a head-to-tail mutual disposition. Each 1-vinylpyrazole displays a $\kappa-\mathrm{N}-\eta^{2}$ C,C' coordination mode with the nitrogen bonded to one rhodium centre and the $\eta^{2}-C, C^{\prime}$ group to the other. To the best of our knowledge, this is the first structurally characterized metal complex featuring such coordination mode. Further, it is worth mentioning that the palladium complex $\mathrm{PdCl}_{2}(\kappa-\mathrm{N}-1$-vinyl-3methyl-pyrazole) $)_{2}$ [9] and the rhodium derivative $\mathrm{RhCl}(\mathrm{IPr})$ ( $\kappa-\mathrm{N}, \eta^{2}-3,5$-dimethyl-1-vinylpyrazole) described by us [4] are the only coordination compounds containing a 1-vinylpyrazole 


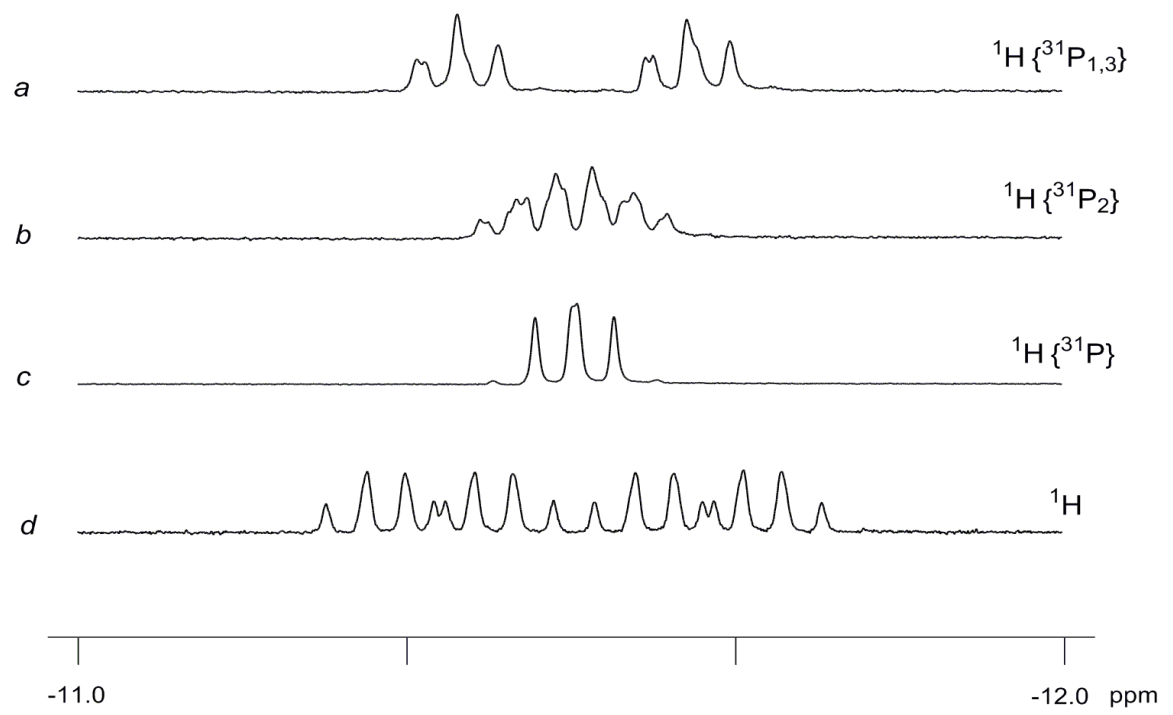

Figure 4. Hydrido region of the ${ }^{1} \mathrm{H}$ NMR spectra of 2 in $\mathrm{C}_{6} \mathrm{D}_{6} / \mathrm{CD}_{2} \mathrm{Cl}_{2}$ at $298 \mathrm{~K}$.

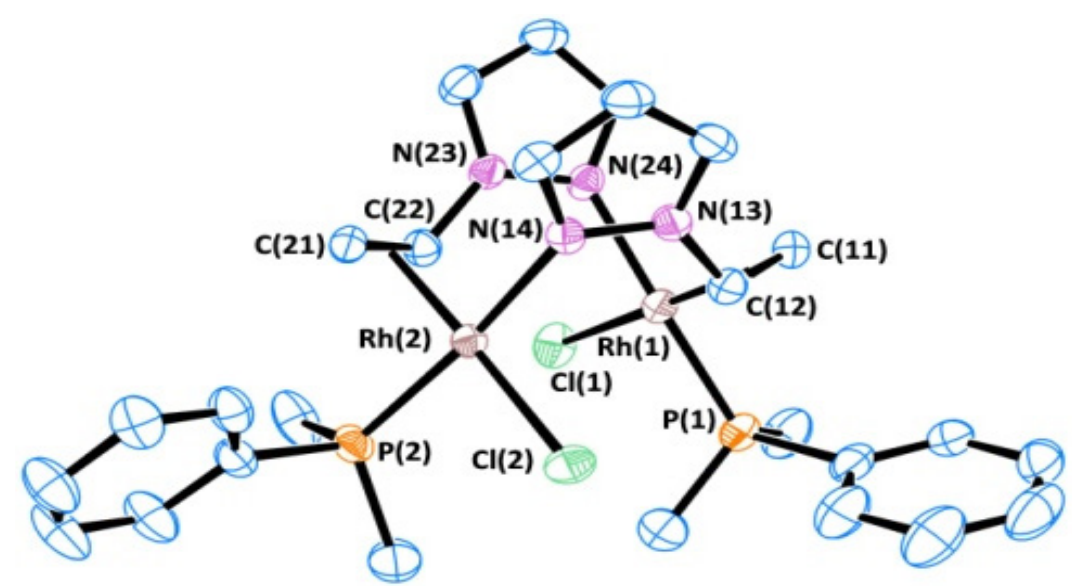

Figure 5. ORTEP view of the X-ray structure of 3. Hydrogen atoms are omitted for clarity. Ellipsoids are at $50 \%$ probability. Selected bond lengths $(\AA)$ and angles $\left(^{\circ}\right)$ (ct: centroid): $\mathrm{R}(1)-\mathrm{N}(24)$ 2.130(3), Rh(1)-P(1) 2.2384(10), Rh(1)-ct[C(11)-C(12)] 1.9585(5), C(11)-C(12) 1.412(5), $\mathrm{R}(2)-\mathrm{N}(14)$ 2.128(2), $\mathrm{Rh}(2)-\mathrm{P}(2)$ 2.2340(10), $\mathrm{Rh}(2)-\operatorname{ct}[\mathrm{C}(21)-\mathrm{C}(22)]$ 1.9620(6), C(21)-C(22) 1.406(4), N(13)-N(14) 1.352(3); N(23)-N(24) 1.360(4), N(24)-Rh(1)-P(1) 173.58(8), N(24)-Rh(1)-Cl(1) 89.52(8), ct[C(11)-C(12)]-Rh(1)-P(1) 92.69(4), ct[C(11)-C(12)]-Rh(1)-Cl(1) 175.77(3), $\mathrm{N}(14)-\mathrm{Rh}(2)-\mathrm{P}(2)$ 170.31(7), N(14)-Rh(2)-Cl(2) 91.45(7), ct[C(21)-C(22)]-Rh(2)-P(2) 89.01(3), ct[C(21)-C(22)]-Rh(2)-Cl(2) 178.23(3).

ligand that have been structurally characterized by X-ray diffraction techniques so far.

The metal centers display a square planar coordination that includes one phosphorus trans to nitrogen $\{\mathrm{N}(24)-\mathrm{Rh}(1)-\mathrm{P}(1)$ 173.58(8), N(14)-Rh(2)-P(2) 170.31(7) $\AA$ \} and one chlorido ligand trans to the $\eta^{2}-\mathrm{CC}^{\prime}$ group $\{\mathrm{ct}[\mathrm{C}(11)-\mathrm{C}(12)]-\mathrm{Rh}(1)-$ $\mathrm{Cl}(1)$ 175.77(3), $\operatorname{ct}[\mathrm{C}(21)-\mathrm{C}(22)]-\mathrm{Rh}(2)-\mathrm{Cl}(2)$ 178.23(3) $\AA\}$. Both pyrazolyl rings lay out of the metal coordination plane $\{\mathrm{N}(13)-\mathrm{N}(14)-\mathrm{Rh}(2)-\mathrm{Cl}(2) \quad 66.0(2), \mathrm{N}(23)-\mathrm{N}(24)-\mathrm{Rh}(1)-\mathrm{Cl}(1)$ $\left.71.8(2)^{\circ}\right\}$. Further, the two $\eta^{2}-C^{\prime}$ bonds are almost perpendicular to the coordination plane $\{\mathrm{C}(11)-\operatorname{ct}[\mathrm{C}(11)-\mathrm{C}(12)]-$ $\mathrm{Rh}(1)-\mathrm{P}(1)$ 86.8(3), C(21)-ct[C(21)-C(22)]-Rh(2)-P(2) 79.7(3) $\left.{ }^{\circ}\right\}$. The large intermetallic distance $\{\operatorname{Rh}(1) \cdots \operatorname{Rh}(2) 3.288(1) \AA\}$ rules out any interaction between the two metal centres. When considering the 3D packing, interestingly anagostic $\mathrm{CH} \cdots \mathrm{Rh}$ interactions generate chains of dinuclear complexes growing parallel to the $\boldsymbol{b}$ axis (Figure 6A). In addition these chains are joined together by means of $\mathrm{CH} \cdots \mathrm{Cl}$ hydrogen bonds (Figure $6 \mathrm{~B})[10]$ rendering double chains which afford the $3 \mathrm{D}$ packing by means of bifurcated $\mathrm{CH} \cdots \mathrm{Cl}$ hydrogen bonds - namely $\mathrm{Cl}(2) \cdots \mathrm{H}(27)-\mathrm{C}(27), \mathrm{Cl}(2) \cdots \mathrm{H}(21 \mathrm{~B})-\mathrm{C}(21))$ (Figure 6C).

The NMR data of $\mathbf{3}$ agrees with the molecular structure found in the solid state. Coordination to rhodium of the alkenyl substituent of 1-vinylpyrazole is reflected in the shielding of signals for the olefinic protons $(\delta 5.15,2.00$, and $1.78 \mathrm{ppm})$ in the ${ }^{1} \mathrm{H}$ NMR spectrum. Indeed two doublets of doublets were observed at $63.5\left(J_{\mathrm{C}-\mathrm{Rh}}=17.0 \mathrm{~Hz}, J_{\mathrm{C}-\mathrm{P}}=2.5 \mathrm{~Hz}\right)$ and $36.0 \mathrm{ppm}$ $\left(J_{\mathrm{C}-\mathrm{Rh}}=17.9 \mathrm{~Hz}, J_{\mathrm{C}-\mathrm{P}}=3.0 \mathrm{~Hz}\right)$ in the ${ }^{13} \mathrm{C}\left\{{ }^{1} \mathrm{H}\right\}$ NMR spectrum. 


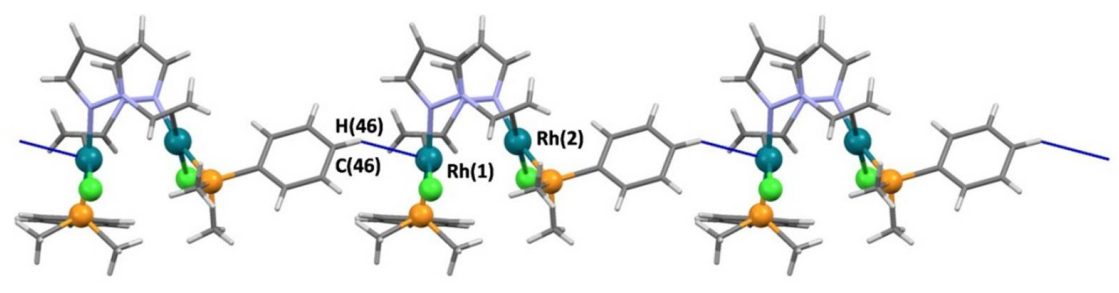

(A)

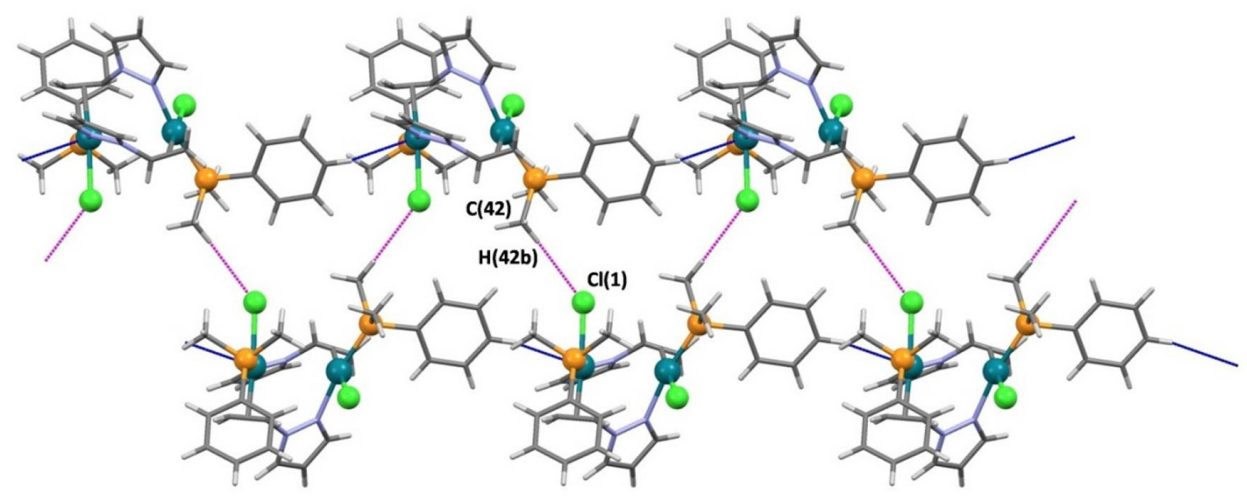

(B)

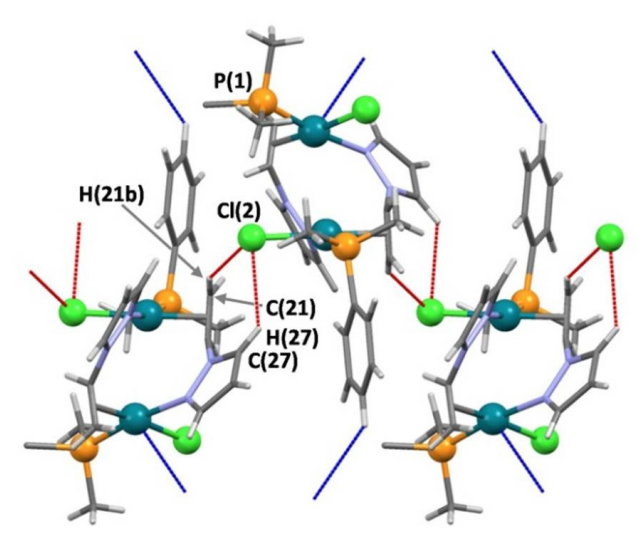

(C)

Figure 6. (A) $\mathrm{CH} \cdots \mathrm{Rh}$ anagostic interaction (blue) between adjacent molecules of $\mathbf{3}$ forming chains along $b$. Most hydrogen atoms are omitted for clarity, $\mathrm{H}(46) \cdots \mathrm{Rh}(1) 2.975(1) \AA ; \mathrm{C}(46)-\mathrm{H}(46)-\mathrm{Rh}(1) 140.8(2)^{\circ}$. (B) View of the $\mathrm{C}(42)-\mathrm{H}(42 \mathrm{~b}) \cdots \mathrm{Cl}(1)$ contacts (violet) along with the anagostic $\mathrm{CH} \cdots \mathrm{Rh}$ interaction (blue), $\mathrm{H}(42 \mathrm{~b}) \cdots \mathrm{Cl}(1)$ 2.881(1) $\AA$; $\mathrm{C}(42)-\mathrm{H}(42 \mathrm{~b})-\mathrm{Rh}(1) 159.5(3)^{\circ}$. (C) View of the $\mathrm{C}(27)-\mathrm{H}(27) \cdots \mathrm{Cl}(2)$ and $\mathrm{C}(21)-$ $\mathrm{H}(21 \mathrm{~b}) \cdots \mathrm{Cl}(2)$ contacts (red) along with the anagostic $\mathrm{CH} \cdots \mathrm{Rh}$ contacts (blue). Only the ipso carbon of the $\mathrm{P}(1)$-phenyl ring is shown, $\mathrm{H}(27) \cdots \mathrm{Cl}(2) 2.849(1) \AA \AA$; $(27)-\mathrm{H}(27)-\mathrm{Cl}(2) 135.4(2)^{\mathrm{o}} ; \mathrm{H}(21 \mathrm{~b}) \cdots \mathrm{Cl}(2) 2.73(5) \AA ̊ \mathrm{C}(21)-\mathrm{H}(21 \mathrm{~b})-\mathrm{Cl}(2) 150(4)^{\mathrm{o}}$.

The ${ }^{31} \mathrm{P}\left\{{ }^{1} \mathrm{H}\right\}$ NMR spectrum displays a sole doublet indicating the equivalence of the phosphines.

The different reactivity for 2-vinylpyridine and 1-vinylpyrazole with Rh-phosphine systems could be in principle surprising. However, related to the stability of the new complexes, the higher coordination ability of pyridine compared to pyrazole could explain the reversible process observed for the latter. Indeed, olefinic $\mathrm{C}-\mathrm{H}$ bond of 1-vinylpyrazole is less acidic than that of 2-vinylpyridine, due to the presence of a nitrogen atom directly attached to the alkene in the former, which may increase the barrier for the cleavage step. The fact that is possible to isolate hydrido-rhodium-alkenylpyridine species in the presence of a small phosphine but not with a bulky NHC may be attributed to the stability of the final complexes and not to the barrier for $\mathrm{C}-\mathrm{H}$ activation process, which seems to be easy for 2-vinylpyridine, likely due to the directing group effect of nitrogenated group. The putative hydrido-vinyl- rhodium(III) complex formed for NHC systems could revert to $\mathrm{Rh}^{\mathrm{I}}$ square-planar precursors but is stabilized by the formation of a dinuclear $\mathrm{Rh}^{\mathrm{I}}-\mathrm{Rh}^{\mathrm{III}}$ species for phosphine derivatives that were not suitable for a bulky ligand. 


\section{Conclusion}

In summary, we have described the synthesis of new rhodium-phosphine dinuclear complexes arising from the distinct reactivity of 2-vinylpyridine and 1-vinylpyrazole. In the case of 2-vinylpyridine $\mathrm{C}-\mathrm{H}$ activation of the alkene results in the formation a $\mathrm{Rh}^{\mathrm{I}}-\mathrm{Rh}^{\mathrm{III}}$ mixed valence dinuclear complex with a bridging hydrido ligand and a 2-(pyridin-2-yl)vinyl moiety as a chelate ligand with one rhodium and as a bridge to the other metal atom via a $\eta^{2}$-olefin bond. Several anagostic $\mathrm{Rh} \cdots \mathrm{HC}$ interactions and $\pi$-stacking between aromatic rings were found in the solid state. The small size of the phosphine ligand allows for the assembly of a dinuclear structure containing the $\sigma$-ligand resulting from the $\mathrm{C}-\mathrm{H}$ cleavage. In contrast, 1-vinylpyrazole does not undergo a $\mathrm{C}$-H activation process, resulting in the formation of dinuclear species with 1-vinylpyrazole as a bridge via a nitrogen atom and $\mathrm{a} \eta^{2}$-olefin bond.

\section{Experimental section}

General Considerations. All reactions were carried out with rigorous exclusion of air using Schlenk-tube techniques. The reagents were purchased from commercial sources and were used as received. Organic solvents were dried by standard procedures and distilled under argon prior to use or obtained oxygenand water-free from a Solvent Purification System (Innovative Technologies). The organometallic precursors $\left[\mathrm{Rh}(\mu-\mathrm{Cl})\left(\eta^{2}-\right.\right.$ coe $\left.)_{2}\right]_{2}$ (1) was prepared as previously described [11].Chemical Shifts (expressed in parts per million) are referenced to residual solvent peaks $\left({ }^{1} \mathrm{H},{ }^{13} \mathrm{C}\left\{{ }^{1} \mathrm{H}\right\}\right)$. Coupling constants, $\boldsymbol{J}$, are given in $\mathrm{Hz}$. Spectral assignments were achieved by combination of ${ }^{1} \mathrm{H}-{ }^{1} \mathrm{H}$ COSY, ${ }^{13} \mathrm{C}\left\{{ }^{1} \mathrm{H}\right\}$-APT and ${ }^{1} \mathrm{H}-{ }^{13} \mathrm{C}$ HSQC/HMBC NMR experiments.

\section{Preparation of $\mathrm{Rh}_{2} \mathrm{Cl}_{2}(\mu-\mathrm{H})\left(\mu-\eta^{2}, \kappa^{2}-\mathrm{C}, \mathrm{N}-\mathrm{NC}_{5} \mathrm{H}_{4}-2-(Z) \mathrm{CH}=\mathrm{CH}\right)$} $\left(\mathbf{P P h M e}_{2}\right)_{\mathbf{3}}$ (2). A solution of $\mathbf{1}(200 \mathrm{mg}, 0.279 \mathrm{mmol})$ in $100 \mathrm{~mL}$ of toluene was treated with dimethylphenylphosfine $(120 \mu \mathrm{L}$, $0.837 \mathrm{mmol})$ and 2-vinylpiridine $(30 \mu \mathrm{L}, 0.279 \mathrm{mmol})$ and stirred for $1 \mathrm{~h}$ at room temperature. After filtration through Celite the solvent was evaporated to dryness. Addition of hexane caused precipitation of a red solid, which was washed with hexane (3 x $4 \mathrm{~mL})$ and dried in vacuo. Yield (150 mg, 73\%). ${ }^{1} \mathrm{H}$ NMR (500 MHz, 4:1 C $\left.\mathrm{D}_{6}: \mathrm{CD}_{2} \mathrm{Cl}_{2}, 298 \mathrm{~K}\right): \delta 8.58\left(\mathrm{dd}, J_{\mathrm{H}-\mathrm{P}}=\right.$ $\left.4.6, J_{\mathrm{H}-\mathrm{H}}=4.4,1 \mathrm{H}, \mathrm{H}_{6-\mathrm{py}}\right), 7.64,7.53$, and $7.12\left(\mathrm{dd}, J_{\mathrm{H}-\mathrm{P}}=9.0\right.$, $\left.J_{\mathrm{H}-\mathrm{H}}=7.1,6 \mathrm{H}, \mathrm{H}_{\mathrm{o}-\mathrm{Ph}}\right), 7.3-7.1\left(\mathrm{~m}, 9 \mathrm{H}, \mathrm{H}_{\mathrm{Ph}}\right), 6.87\left(\mathrm{dd}, J_{\mathrm{H}-\mathrm{H}}=\right.$ $\left.7.6,7.1,1 \mathrm{H}, \mathrm{H}_{4-\mathrm{py}}\right), 6.54\left(\mathrm{ddd}, J_{\mathrm{H}-\mathrm{H}}=4.8, J_{\mathrm{H}-\mathrm{P}}=4.6,3.0,1 \mathrm{H}\right.$, $\mathrm{Rh}-\mathrm{C} \underline{\mathrm{H}}=\mathrm{CH}), 6.44\left(\mathrm{dd}, J_{\mathrm{H}-\mathrm{H}}=7.1,4.4,1 \mathrm{H}, \mathrm{H}_{5-\mathrm{py}}\right), 6.41\left(\mathrm{~d}, J_{\mathrm{H}-\mathrm{H}}\right.$ $\left.=7.6,1 \mathrm{H}, \mathrm{H}_{3-\mathrm{py}}\right), 3.00\left(\mathrm{dddd}, J_{\mathrm{H}-\mathrm{P}}=11.2, J_{\mathrm{H}-\mathrm{H}}=4.8, J_{\mathrm{H}-\mathrm{Rh}}=2.0\right.$, 2.0, 1H, Rh-CH=ㅡㅏ), 2.31, 1.90, 1.79, 1.51, 1.44, and 0.92 (all $\mathrm{d}, J_{\mathrm{H}-\mathrm{P}}=7.8,18 \mathrm{H}, \mathrm{PMe}_{2} \mathrm{Ph}$ ), -11.40 (ddddd, $J_{\mathrm{H}-\mathrm{Rh}}=17,20$ and $J_{\mathrm{H}-\mathrm{P}}=18,50,128,1 \mathrm{H}, \mathrm{Rh}(\mu-\mathrm{H}) .{ }^{13} \mathrm{C}\left\{{ }^{1} \mathrm{H}\right\}$ NMR-APT $(125.6$ $\mathrm{MHz}, 4: 1 \mathrm{C}_{6} \mathrm{D}_{6}: \mathrm{CD}_{2} \mathrm{Cl}_{2}, 298 \mathrm{~K}$ ): $\delta 171.0$ (s, $\mathrm{C}_{2-\mathrm{py}}$ ), 150.1 (s, $\mathrm{C}_{6-\mathrm{py}}$ ), 137.5, 137.2, and 136.8 (all d, $J_{\mathrm{C}-\mathrm{P}}=41, \mathrm{C}_{\mathrm{q}-\mathrm{Ph}}$ ), 136.5 $\left(\mathrm{s}, \mathrm{C}_{4-\mathrm{py}}\right), 133.9$ (m, Rh- $\left.\underline{\mathrm{CH}}=\mathrm{CH}\right), 131.2,130.6$, and 129.7 (all $\left.\mathrm{d}, J_{\mathrm{C}-\mathrm{P}}=8.3, \mathrm{C}_{\mathrm{o}-\mathrm{Ph}}\right), 129.2,129.1$, and 128.7 (all d, $J_{\mathrm{C}-\mathrm{P}}=2.6$,
$\mathrm{C}_{\mathrm{m}-\mathrm{Ph}}$ ), 128.2, 128.1, and 127.8 (all s, $\mathrm{C}_{\mathrm{p}-\mathrm{Ph}}$ ), 118.4 (s, $\mathrm{C}_{5-\mathrm{py}}$ ), $116.0\left(\mathrm{~s}, \mathrm{C}_{3-\mathrm{py}}\right), 59.6\left(\mathrm{ddd}, J_{\mathrm{C}-\mathrm{Rh}}=12.9,3.0, J_{\mathrm{C}-\mathrm{P}}=3.0\right.$, Rh$\mathrm{CH}=\underline{\mathrm{CH}}$ ), 17.8 and 17.2 both d, $J_{\mathrm{C}-\mathrm{P}}=39.2$, Me-P(3)\}, 14.3 and 14.0 both d, $J_{\mathrm{C}-\mathrm{P}}=30$, Me-P(1)\}, 12.5 and 12.4 \{both d, $\left.J_{\mathrm{C}-\mathrm{P}}=26.6, \mathrm{Me}-\mathrm{P}(2)\right\} .{ }^{31} \mathrm{P}\left\{{ }^{1} \mathrm{H}\right\} \mathrm{NMR}\left(202 \mathrm{MHz}, 4: 4 \mathrm{C}_{6} \mathrm{D}_{6}: \mathrm{CD}-\right.$ $\left.{ }_{2} \mathrm{Cl}_{2}, 298 \mathrm{~K}\right): \delta 11.11\left\{\right.$ dddd, $\left.J_{\mathrm{P}-\mathrm{P}}=56,3, J_{\mathrm{P}-\mathrm{Rh}}=176,10, \mathrm{P}(3)\right\}$, $10.34\left\{\right.$ dddd, $\left.J_{\mathrm{P}-\mathrm{P}}=27,3, J_{\mathrm{P}-\mathrm{Rh}}=115,3, \mathrm{P}(1)\right\},-1.76\left(\mathrm{dddd}, J_{\mathrm{P}-\mathrm{P}}\right.$ $\left.=56,27, J_{\mathrm{P}-\mathrm{Rh}}=111,7, \mathrm{P}(2)\right\}$.

In situ formation of $\mathrm{Rh}_{2} \mathrm{Cl}_{2}\left(\mu-\eta^{2}-\mathrm{N}_{2} \mathrm{C}_{3} \mathrm{H}_{3}-\mathbf{1}-\mathrm{CH}=\mathrm{CH}_{2}\right)_{2}$ $(\mathbf{P P h M e})_{2} \mathbf{2}$ (3). A solution of $\mathbf{1}(20 \mathrm{mg}, 0.028 \mathrm{mmol})$ in a mixture of $0.4 \mathrm{~mL}$ of $\mathrm{C}_{6} \mathrm{D}_{6}$ and $0.1 \mathrm{~mL}$ of $\mathrm{CD}_{2} \mathrm{Cl}_{2}$ was treated with dimethylphenylphosfine $(8 \mu \mathrm{L}, 0.056 \mathrm{mmol})$ and 1-vinylpyrazole $(5 \mu \mathrm{L}, 0.56 \mathrm{mmol})$. NMR spectra were recorded after $1 \mathrm{~h}$ at room temperature. ${ }^{1} \mathrm{H} \mathrm{NMR}\left(500 \mathrm{MHz}, 4: 1 \mathrm{C}_{6} \mathrm{D}_{6}: \mathrm{CD}_{2} \mathrm{Cl}_{2}\right.$, $298 \mathrm{~K}): \delta 7.63\left(\mathrm{dd}, J_{\mathrm{H}-\mathrm{P}}=8.1, J_{\mathrm{H}-\mathrm{H}}=7.6,4 \mathrm{H}, \mathrm{H}_{\mathrm{o}-\mathrm{Ph}}\right), 6.89(\mathrm{ddd}$, $\left.J_{\mathrm{H}-\mathrm{P}}=8.8, J_{\mathrm{H}-\mathrm{H}}=7.6,7.2,4 \mathrm{H}, \mathrm{H}_{\mathrm{m}-\mathrm{Ph}}\right), 6.79\left(\mathrm{dt}, J_{\mathrm{H}-\mathrm{H}}=7.2, J_{\mathrm{H}-\mathrm{H}}\right.$ $\left.=3.0,2 \mathrm{H}, \mathrm{H}_{\mathrm{p}-\mathrm{Ph}}\right), 6.70\left(\mathrm{~d}, J_{\mathrm{H}-\mathrm{H}}=1.9,2 \mathrm{H}, \mathrm{H}_{3-\mathrm{pz}}\right), 5.99\left(\mathrm{~d}, J_{\mathrm{H}-\mathrm{H}}=\right.$ 2.1, $\left.2 \mathrm{H}, \mathrm{H}_{5-\mathrm{pz}}\right), 5.15\left(\mathrm{~m}, 2 \mathrm{H}, \mathrm{C} \underline{\mathrm{H}}=\mathrm{CH}_{2}\right), 4.94\left(\mathrm{dd}, J_{\mathrm{H}-\mathrm{H}}=2.1\right.$, 1.9, 2H, $\left.\mathrm{H}_{4-\mathrm{pz}}\right), 2.00\left(\mathrm{~d}, J_{\mathrm{H}-\mathrm{H}}=9.1,2 \mathrm{H}, \mathrm{CH}=\mathrm{CH}_{2}\right), 1.78(\mathrm{~m}, 2 \mathrm{H}$, $\mathrm{CH}=\mathrm{CH}_{2}$ ), 1.71 and 1.47 (both $\mathrm{d}, J_{\mathrm{H}-\mathrm{P}}=10.8,12 \mathrm{H}, \mathrm{MeP}$ ). ${ }^{13} \mathrm{C}\left\{{ }^{1} \mathrm{H}\right\}$ NMR-APT $\left(125.6 \mathrm{MHz}, 4: 1 \mathrm{C}_{6} \mathrm{D}_{6}: \mathrm{CD}_{2} \mathrm{Cl}_{2}, 298 \mathrm{~K}\right): \delta$ $139.3\left(\mathrm{~s}, \mathrm{C}_{3-\mathrm{pz}}\right), 134.8\left(\mathrm{~d}, J_{\mathrm{C}-\mathrm{P}}=44.5, \mathrm{C}_{\mathrm{q}-\mathrm{Ph}}\right), 131.3\left(\mathrm{~d}, J_{\mathrm{C}-\mathrm{P}}=8.7\right.$, $\left.\mathrm{C}_{\mathrm{o}-\mathrm{Ph}}\right), 129.2\left(\mathrm{~s}, \mathrm{C}_{\mathrm{p}-\mathrm{Ph}}\right), 128.5\left(\mathrm{~s}, \mathrm{C}_{5-\mathrm{pz}}\right), 128.1\left(\mathrm{~d}, J_{\mathrm{C}-\mathrm{P}}=3.0, \mathrm{C}_{\mathrm{m}}\right.$ $\left.{ }_{-\mathrm{Ph}}\right), 104.5\left(\mathrm{~s}, \mathrm{C}_{4-\mathrm{pz}}\right), 63.5\left(\mathrm{dd}, J_{\mathrm{C}-\mathrm{Rh}}=17.0, J_{\mathrm{C}-\mathrm{P}}=2.5, \underline{\mathrm{C}} \mathrm{H}=-\right.$ $\left.\mathrm{CH}_{2}\right), 36.0\left(\mathrm{dd}, J_{\mathrm{C}-\mathrm{Rh}}=17.9, J_{\mathrm{C}-\mathrm{P}}=3.0, \mathrm{CH}=\underline{\mathrm{CH}}_{2}\right), 14.8$ and 11.8 (both d, $\left.J_{\mathrm{C}-\mathrm{P}}=30.0, \mathrm{PMe}\right) .{ }^{31} \mathrm{P}\left\{{ }^{1} \mathrm{H}\right\} \mathrm{NMR}(202 \mathrm{MHz}, 4: 1$ $\left.\mathrm{C}_{6} \mathrm{D}_{6}: \mathrm{CD}_{2} \mathrm{Cl}_{2}, 298 \mathrm{~K}\right): \delta 17.1\left(\mathrm{~d}, J_{\mathrm{Rh}-\mathrm{P}}=150.3, \mathrm{PMe}\right)$.

Solid state structure determinations. Intensities were collected using a Bruker APEX (2) or a Bruker SMART APEX-DUO (3) diffractometer with graphite-monochromated Mo K $\alpha$ radiation $(\lambda=0.71073 \AA)$ following standard procedures. Intensities were integrated and corrected for absorption effects using the SAINT+ [12] and SADABS [13] programs, included in the APEX2 package. The structure was solved by the Patterson's method. Refinement was carried out by full-matrix leastsquare procedure (based on $\mathrm{F}_{0}{ }^{2}$ ) using anisotropic temperature factors for all non-hydrogen atoms. Calculations were performed with SHELX-97 [14] program implemented in the WinGX package [15].

Crystal data and structure refinement for $\mathrm{Rh}_{2} \mathrm{Cl}_{2}(\mu-\mathrm{H})$ $\left(\mu-\eta^{2}, \kappa^{2}-\mathrm{C}, \mathbf{N}-\mathrm{NC}_{5} \mathbf{H}_{4}-\mathbf{2}-(Z) \mathbf{C H}=\mathbf{C H}\right)\left(\mathbf{P P h M e}_{2}\right)_{3} \quad$ (2). $\mathrm{C}_{31} \mathrm{H}_{40}$ $\mathrm{Cl}_{2} \mathrm{NP}_{3} \mathrm{Rh}_{2}, \mathrm{M}=796.27 \mathrm{~g} \mathrm{~mol}^{-1}, \mathrm{~T}=100(2) \mathrm{K}$, monoclinic, $\mathrm{P} 2{ }_{1} / \mathrm{c}, a=20.1886(14) \AA, b=8.4474(6) \AA, c=18.6894(13) \AA$, $\beta=90.6460(10)^{\circ}, V=3187.1(4) \AA^{3}, Z=4, D_{\text {calc }}=1.659 \mathrm{~g} \mathrm{~cm}^{-3}$, $\mu=1.376 \mathrm{~mm}^{-1}, \mathrm{~F}(000)=1608$, red prism, $0.260 \times 0.190 \mathrm{x}$ $0.060 \mathrm{~mm}, \theta$ range for data collection: $2.018^{\circ}$ to $28.658^{\circ}$, limiting indices: $-26 \leq h \leq 27,-11 \leq k \leq 11,-24 \leq l \leq 24$, reflections collected/unique: $41884 / 7758[\mathrm{R}(\mathrm{int})=0.0293]$, data/restraints/ parameters: $7758 / 0 / 512, \mathrm{GOF}=1.040, R_{1}=0.0216[\mathrm{I}>2 \sigma(I)]$, 0.0263 (all data), $\mathrm{w} R_{2}=0.0497[\mathrm{I}>2 \sigma(I)], 0.0519$ (all data), largest diff. peak and hole: 0.759 and $-0.331 \mathrm{e} \cdot \AA^{-3}$. CCDC deposit number 1504390 . 
Crystal data and structure refinement for $\left[\mathbf{R h}_{2} \mathbf{C l}_{\mathbf{2}}\left(\mu-\eta^{2}\right.\right.$, $\left.\mathbf{N}_{\mathbf{2}} \mathbf{C}_{3} \mathbf{H}_{3} \mathbf{- 1}-\mathbf{C H}=\mathbf{C H}_{2}\right)(\mathbf{P P h M e})_{3} \mathbf{I}_{\mathbf{2}}$ (3). $\mathrm{C}_{26} \mathrm{H}_{34} \mathrm{Cl}_{2} \mathrm{~N}_{4} \mathrm{P}_{2} \mathrm{Rh}_{2}, M$ $=741.23, T=170(2) \mathrm{K}$, orthorhombic, $\mathrm{P} 2{ }_{1} 2_{1} 2_{1}, a=10.965(4)$ $\AA, b=12.312(4) \AA, c=22.143(7) \AA, V=2989.2(16) \AA^{3}, Z=4$, $D_{\text {calc }}=1.647 \mathrm{~g} \mathrm{~cm}^{-3}, \mu=1.412 \mathrm{~mm}^{-1}, \mathrm{~F}(000)=1488$, red prism, $0.330 \times 0.150 \times 0.130 \mathrm{~mm}, \theta$ range for data collection: $1.839^{\circ}$ to $29.547^{\circ}$, limiting indices: $-15 \leq h \leq 15,-15 \leq k \leq 17,-30 \leq l \leq 30$, reflections collected/unique 62426/8056 [R(int) $=0.0374$ ], data/ restraints/parameters: 8056/0/354, GOF $=1.046, R_{1}=0.0223$ $[\mathrm{I}>2 \sigma(I)], 0.0248$ (all data), $\mathrm{w} R_{2}=0.0492[\mathrm{I}>2 \sigma(I)], 0.0500$ (all data), absolute structure parameter: 0.48(2), largest diff. peak and hole: 0.507 and $-0.486 \mathrm{e} \cdot \AA^{-3}$. CCDC deposit number 1504391.

\section{Acknowledgment}

Financial support from the Ministerio de Economía y Competitividad (MINECO/FEDER) of Spain (Proyect CTQ201342532-P), the Diputación General de Aragón and Fondo Social Europeo (DGA/FSE-E07), and CONSOLIDER INGENIO-2010 under the Project MULTICAT (CSD2009-00050) is gratefully acknowledged.

\section{References}

1. (a) Kakiuchi, F.; Murai, S. Acc. Chem. Res. 2002, 35, 826-834. (b) Ritleng, V.; Sirlin, C.; Pfeffer, M. Chem. Rev. 2002, 102, 17311769. (c) Godula, K.; Sames, D. Science 2006, 312, 67-72. (d) Campeau, L.-C.; Fagnou, K. Chem. Commun. 2006, 1253-1264. (e) Park, Y. J.; Park, J.-W.; Jun, C.-H. Acc. Chem. Res. 2008, 41, 222-234. (f) Colby, D. A.; Bergman, R. G.; Ellman, J. A. Chem. Rev. 2010, 110, 624-655. (g) Wencel-Delord, J.; Dröge, T.; Liu, F.; Glorius, F. Chem. Soc. Rev. 2011, 40, 4740-4761. (h) Li, B.; Dixneuf, P. H. Chem. Soc. Rev. 2013, 42, 5744-5767. (i) Moselage, M.; Li, J.; Ackermann, L. ACS Catal. 2016, 6, 498-525.

2. See for example: (a) Chatani, N.; Asaumi, T.; Yorimitsu, S.; Ikeda, T.; Kakiuchi, F.; Murai, S. J. Am. Chem. Soc. 2001, 123, 1093510941. (b) Shabashov, D.; Daugulis, O. Org. Lett. 2005, 7, 36573659. (c) Aïssa, C.; Fürstner, A. J. Am. Chem. Soc. 2007, 129, 14836-14837. (d) Mo, F.; Dong, G. Science 2014, 345, 68-72. (e) Liu, B.; Zhou, T.; Li, B.; Xu, S.; Song, H.; Wang, B. Angew. Chem. Int. Ed. 2014, 53, 4191-4195. (f) Martínez, A. M.; Echavarren, J.; Alonso, I.; Rodríguez, N.; Gómez Arrayás, R.; Carretero, J. C.
Chem. Sci. 2015, 6, 5802-5814. (g) Luo, C.-Z.; Gandeepan, P.; Wu, Y.-C.; Tsai, C.-H.; Cheng, C.-H. ACS Catal. 2015, 5, 48374841. (h) Hong, S. Y.; Kwak, J.; Chang, S. Chem. Commun. 2016, 52, 3159-3162.

3. Azpíroz, R.; Di Giuseppe, A.; Castarlenas, R.; Pérez-Torrente, J. J.; Oro, L. A. Chem. Eur. J. 2013, 19, 3812-3816.

4. Azpíroz, R.; Rubio-Pérez, L.; Di Giuseppe, A.; Passarelli, V.; Lahoz, F. J.; Castarlenas, R.; Pérez-Torrente, J. J.; Oro, L. A. ACS Catal. 2014, 4, 4244-4253.

5. (a) Herrmann, W. A. Angew. Chem. Int. Ed. 2002, 41, 1290-1309. (b) Arduengo III, A. J.; Iconaru, L. I. Dalton Trans. 2009, 69036914. (c) Díez-González, S.; Marion, N.; Nolan, S. P. Chem. Rev. 2009, 109, 3612-3676. (d) Hopkinson, M. N.; Richter, C.; Schedler, M.; Glorius, F. Nature 2014, 510, 485-496. (e) Mata, J. A.; Hahn, F. E.; Peris, E. Chem. Sci. 2014, 5, 1723-1732.

6. (a) Burgess, K.; Holden, H. D.; Johnson, B. F. G.; Lewis, J.; Hursthouse, M. B.; Walker, N. P. C.; Deeming, A. J.; Manning, P. J.; Peters, R. J. Chem. Soc. Dalton Trans. 1985, 85-90. (b) Wong, W.-Y.; Wong, W.T. J. Organomet. Chem. 1996, 513, 27-29. (c) Müller, J.; Hirsch, C.; Ha, K. Z. Anorg. Allg. Chem. 2003, 629, 2180-2185. (d) Navarro, J.; Sola, E.; Martín, M.; Dobrinovitch, I. T.; Lahoz, F. J.; Oro, L. A. Organometallics 2004, 23, 1908-1917. (e) Cabeza, J. A.; del Rio, I.; Fernández-Colinas, J. M.; García-Granda, S.; Martinez-Méndez, L.; Pérez-Carreño, E. Chem. Eur. J. 2004, 10, 6265-6278. (f) Azam, K. A.; Bennett, D. W.; Hassan, M. R.; Haworth, D. T.; Hogarh, G.; Kabir, S. E.; Lindeman, S. V.; Salassa, L.; Simi, S. R.; Siddiquee, T. A. Organometallics 2008, 27, 5163-5166.

7. Martinez, C. R.; Iverson, B. L. Chem. Sci. 2012, 3, 2191-2201 and references therein.

8. (a) Brookhart, M.; Green, M. L. H.; Parkin, G. Proc. Natl. Acad. Sci. U.S.A. 2007, 104, 6908-6914. (b) Harrison, J. A.; Nielson, A. J.; Sajjad, M. A.; Saunders, G. C.; Schwerdtfeger, P. Eur. J. Inorg. Chem. 2016, 64-77.

9. Sokol V. I.; Porai-Koshits, M. A.; Vardosanidze, T. O.; Voropaev, V. N.; Domnina, E. S.; Skvortsova, G. G. Koord. Khim. 1983, 9, 1539-1543.

10. Aakeröy, C. B.; Evans, T. A.; Seddon, K. R.; Pálinkó, I. New J. Chem. 1999, 145-152.

11. van der Ent, A.; Onderdelinden, A. L.; Schunn R. A. Inorg. Synth. 1973, 14, 92-95.

12. SAINT+, version 6.01; Bruker AXS, Inc.; Madison, WI, 2001

13. Sheldrick, G. M., SABADS, University of Göttingen: Göttingen, Germany, 1999.

14. (a) Sheldrick, G. M. SHELXL-97, University of Göttingen: Göttingen, Germany, 1997. (b) Sheldrick, G. M. Acta Crystallogr. 2008, A64, 112-122.

15. Farrugia, L. J. J. Appl. Crystallogr. 1999, 32, 837-838. 